\title{
Mortality from lung cancer in Ontario uranium miners
}

\author{
R A Kusiak, A C Ritchie, J Muller, J Springer
}

\begin{abstract}
Mortality from lung cancer was greater in Ontario uranium miners than in the general male population of Ontario (observed $=152$, expected $=67 \cdot 6$, standardised mortality ratio 225, 95\% confidence interval 191-264). Part of the excess of lung cancer may be because the proportion of men who are smokers or have smoked is greater in uranium miners than in Ontario men. Smoking does not explain the whole excess. Mortality from lung cancer in Ontario uranium miners is clearly related to exposure to short lived radon progeny. The excess relative risk of lung cancer from the same degree of exposure to short lived radon progeny is greatest five to 14 years after exposure and less subsequently. It is greater in men under the age of 55 years and less in older men. Part of the excess of lung cancer mortality in Ontario uranium miners is probably also due to exposure to arsenic that occurred earlier in gold mines. In Ontario uranium miners, the lung cancer mortality from exposure to arsenic increases as the intensity of exposure to short lived radon progeny increases. This finding is consistent with the hypothesis that the risk of lung cancer from exposure to arsenic is enhanced by exposure to other carcinogens. In Ontario uranium miners, the proportion of lung cancers that are small cell carcinomas is greater than in the general population. The proportion of small cell carcinomas is especially
\end{abstract}

Health and Safety Studies Unit, Ontario Ministry of Labour

R A Kusiak

Mount Sinai and Toronto Hospitals, University of Toronto

A C Ritchie

Ontario Ministry of Labour (retired)

J Muller

Ontario Geological Survey, Ministry of Northern Development and Mines

J Springer great five to 14 years after exposure to short lived radon progeny and in men who die from lung cancer at younger ages.

(British Fournal of Industrial Medicine 1993;50:920-928)

Previous reports ${ }^{12}$ have noted an excess of mortality from lung cancer in Ontario uranium miners. This increase is caused in large part by exposure to short lived radon progeny. ${ }^{2}$ The earlier reports also noted that the incidence of lung cancer is greater in uranium miners who also worked in Ontario gold mines than in other Ontario uranium miners. A recent report has shown that exposure to arsenic and short lived radon progeny contributes to the excess of lung cancer in Ontario gold miners and that there may be an excess of lung cancer among men who began mining nickel and copper in Ontario before $1935 .^{3}$

Uranium mining began in Ontario in the mid1950s. The earlier reports considered mortality in a cohort of Ontario uranium miners for the years 1955 to $1977^{1}$ and 1955 to $1981 .^{2}$ In this report, the period of observation for mortality has been extended by five years to include the years from 1955 to 1986. Lung cancer mortality has been described with a model that takes into account exposure to short lived radon progeny, age, and time since exposure. ${ }^{4}$ Particular attention is given to the relation between the increased mortality from lung cancer and exposure to arsenic in Ontario gold mines, exposure to short lived radon progeny, and the combined effect of these two exposures. The relation between exposure to short lived radon progeny and the histological type of carcinoma, and the role of smoking in the excess of lung cancer in Ontario uranium miners are also considered.

\section{Materials and methods}

DEFINITION OF COHORT

This is a historical prospective cohort mortality study of Ontario uranium miners. Since 1928, all miners in Ontario have been required to attend annually the chest clinics operated by the Government of Ontario to be certified as being fit 
to work in a job in the mining industry in which they are exposed to silica dust. Uranium mill workers also attended the chest clinic because they were exposed to dust from the ores that were processed. The records kept at the chest clinics were used to assemble the cohort of Ontario miners.

Uranium miners in this study are defined as men who either attended a chest clinic after 1954 and reported that they had worked for at least two weeks in a uranium mine in Ontario, or who were reported by a uranium mining company to have been exposed to short lived radon progeny underground in a uranium mine in Ontario. In all 26674 uranium miners including 1344 uranium mill workers were identified.

There were 1359 uranium miners who also worked in uranium mines outside Ontario. These miners were excluded from the study because their exposures to short lived radon progeny in uranium mines outside the province were not available to us. Another 558 uranium miners who also mined asbestos were excluded to remove mortality from lung cancer related to asbestos. Another 1613 men who either worked in jobs on the surface where there was no exposure to short lived radon progeny or did not have their exposure to short lived radon progeny recorded were also excluded from the analysis. Fifty eight women were excluded from the analysis and another 1740 men were excluded because their dates of birth were either missing or in error. Thus 21346 male uranium miners remained in the study.

\section{MORTALITY SEARCH}

Deaths were found by linking the list of miners in the cohort with the Canadian Mortality Database of deaths that occurred between 1955 and 1986 . The list of miners, obtained from the chest clinics, contained each miner's full name, date of birth, and country of birth. Social insurance numbers (SINs) were also on the list for the $13469(63 \%)$ uranium miners in the study who attended a chest clinic after the introduction of SINs in 1965. The SIN Registry was used by Statistics Canada to obtain additional personal identifying information, such as mother's maiden name, that would also be recorded on the death certificate. The personal identifying information recorded at the chest clinic and those that were obtained from the SIN Registry were used to identify deaths recorded in the Canadian Mortality Database. Details of the methods used have been reported previously. ${ }^{12}$

\section{ALIVE FOLLOW UP}

Uranium miners and other miners in the study were linked by Statistics Canada to income tax returns of Canadians. The SINs were used to link the list of miners with income tax returns for the years 1986, 1987, and 1988. When a miner's SIN was not available, Statistics Canada used a probabilistic file linkage procedure to find the miner's income tax returns for the years 1986 and 1987.

\section{STATISTICAL METHODS}

Person-years at risk for each miner were counted from the year of the first chest examination after 1954 at which he reported that he had worked at least two weeks in a uranium mine or when a uranium mining company reported that the miner had been exposed to short lived radon progeny in Ontario, whichever occurred first. Person-years at risk were counted up to the time of death, the time when the miner began working in a uranium mill, reached the age of 75 years, or when the study ended, whichever occurred first.

The expected number of deaths from lung cancer was calculated from age specific and calendar period specific lung cancer mortality of Ontario males. Mortality in miners over the age of 75 years was much lower than in the Ontario male population in the same age groups. The low observed death rates in miners above the age of 75 were unlikely to be real. The file linkage procedure failed to find all of the deaths among the miners in the study group, particularly the deaths of those miners who retired outside of Canada and died there. To limit the downward bias on the SMR from the underascertainment of mortality, person-years at risk and deaths over the age of 75 were excluded.

Lagged exposures to arsenic and short lived radon progeny were calculated by accumulating the exposures in those years in which the interval between the calendar year of exposure and the calendar year at risk exceeded the lag interval. Exposure in the time window five to 14 years is the difference between exposure lagged five years and exposure lagged 15 years.

\section{EXPOSURE TO SHORT LIVED RADON PROGENY}

Exposure to short lived radon progeny is expressed in working level-months (WLM). A working level (WL) is defined as $1.3 \times 10^{5} \mathrm{MeV}$ of potential $\alpha$ energy/l air. A working level-month is exposure to 1 WL for 170 hours. The levels of short lived radon progeny in gold and uranium mines were measured by the Kuznetz method and the measuring instruments were calibrated by provincial government agencies.

Uranium mining began in Ontario in 1955 but the levels of short lived radon progeny in the mines were not measured until 1958. By 1960, the levels were measured by all Ontario uranium mine operators. Amounts of radon decay products in the earlier years were estimated by extrapolation. In no uranium mine was the period of extrapolation more than five years. 
Exposure to short lived radon progeny in the uranium mines during each calendar year was determined for each miner in the study. For the years from 1955 to 1968 , the exposure was calculated from the average amount of short lived radon progeny in the uranium mine or mines in which the man had worked and the work history given during his annual visit to the chest clinic. After 1968, each miner's annual exposure was calculated by the uranium mining company where he was employed. The mining company used the man's daily time card and recent measurements of short lived radon progeny in the part of the mine where the miner reported that he had been working to determine his exposure to short lived radon progeny during each working day. These daily exposures were accumulated into annual exposures.

The work histories reported before 1968 by a small random sample of uranium miners were compared with the employment records kept by the uranium mining companies. ${ }^{2}$ The comparison showed that the exposures derived from the two sources of employment data agreed well.

There were 3513 uranium miners who also worked in gold mines in Ontario. Gold mining began in Ontario before 1900 but the short lived radon progeny in the gold mines were measured for the first time in 1961. Most of the measurements in the gold mines, however were made in the $1980 \mathrm{~s}^{3}$

Each miner's exposure to short lived radon progeny in gold mines was determined with the measurements of short lived radon progeny made in the gold mines and the work histories reported by each miner. The radon decay products in active parts of gold mines were assumed to be representative of the gold miners' exposures after 1945 when the ventilation rates in the gold mines began to be increased. The average amounts measured in dead ends were assumed to be representative of earlier exposures. When no measurements were made in a gold mine, the values in nearby gold mines in the same geological setting were used.

For the uranium miners who also worked in gold mines, the average cumulative exposure to short lived radon progeny in gold mines was 2 WLM and $99 \%$ of the cumulative exposures were less than 22 WLM. The average cumulative exposure to short lived radon progeny in uranium mines was 30 WLM and $99 \%$ of the cumulative exposures were less than 255 WLM.

The average duration of employment in Ontario uranium mines was 2.6 years and $56 \%$ of the miners began mining uranium before 1965 . For uranium miners who began mining before 1965, the mean exposure to short lived radon progeny in the uranium mines was $1.3 \mathrm{WL}$ but in some mines the averages were as high as 8 WL. For miners who began mining uranium after 1964, the mean exposure to short lived radon progeny was $0 \cdot 2 \mathrm{WL}$.

\section{EXPOSURE TO ARSENIC}

For each gold miner in Ontario, an estimate of his exposure to arsenic was made by multiplying the duration of his employment underground in gold mines with the concentration of arsenic in the rocks in the mine or mines in which he worked. ${ }^{3}$ Few measurements of the concentration of airborne arsenic in Ontario mines are available, but in most of the gold mines the concentration of arsenic in the rocks is known. The amount of arsenic in the rocks in gold mines ranges from less than $0.02 \%$ to over $1 \%$. The amount of arsenic in the rocks in uranium mines in Ontario is in the range $0.01-0.06 \% .^{3}$ In considering the role of arsenic in causing cancers of the lung in uranium miners, only the exposure to arsenic in the gold mines was assessed. Exposure to arsenic in Ontario uranium mines or other mines that do not contain gold bearing ores was not included in this analysis.

\section{HISTOLOGY}

Hospitals in which miners with lung cancer were treated were asked to provide tissue blocks, slides, or occasionally cytological specimens in all cases in which a biopsy or necropsy was performed. The diagnoses were confirmed and the carcinomas were classified according to the World Health Organisation classification. ${ }^{6}$

\section{SMOKING}

Several surveys of the smoking habits of Ontario uranium miners are available. The smoking history of each man employed in an Ontario uranium mine in $1974^{7}$ and of a random sample of uranium miners born before $1938^{2}$ have been determined. Beginning in 1976, each miner's smoking history was recorded when he made his annual visit to a chest clinic. In 1990-91, a questionnaire about smoking was sent by post to all uranium miners in the Province of Ontario whose addresses could be found.

\section{Results}

\section{ALIVE FOLLOW UP}

If both uranium and non-uranium miners are included, the alive follow up includes 54208 miners. Of these, 81 were women who were excluded from the mortality analysis.

There were 37373 miners in the alive follow up study who reported a SIN to the chest clinics. Of these miners, $30589^{\circ}(82 \%)$ had submitted an income tax return in 1986, 1987, or 1988 and 4993 (13\%) had died during the study period leaving 1791 (5\%) unaccounted for. Of the 16835 miners 
Table 1 Lung cancer mortality in uranium miners: combined effect of mining uranium, gold, and nickel and copper in different periods

\begin{tabular}{|c|c|c|c|c|c|c|c|c|c|c|c|c|}
\hline \multirow{2}{*}{$\begin{array}{l}\text { Year miner } \\
\text { first mined } \\
\text { gold in } \\
\text { Ontario }\end{array}$} & \multicolumn{4}{|c|}{ Never mined nickel and copper } & \multicolumn{4}{|c|}{ Mined nickel and copper in Ontario } & \multicolumn{4}{|c|}{ Total } \\
\hline & $O$ & $E$ & $S M R$ & $\begin{array}{l}\text { No of } \\
\text { miners }\end{array}$ & $O$ & $E$ & $S M R$ & $\begin{array}{l}\text { No of } \\
\text { men }\end{array}$ & $O$ & $E$ & $S M R$ & $\begin{array}{l}\text { No of } \\
\text { men }\end{array}$ \\
\hline $\begin{array}{l}\text { Never } \\
\leqslant 1945 \\
\geqslant 1946 \\
\text { Total }\end{array}$ & $\begin{array}{l}39 \\
26 \\
22 \\
87\end{array}$ & $\begin{array}{r}16.9 \\
9.6 \\
12.4 \\
39.0\end{array}$ & $\begin{array}{l}230 \\
270 \\
177 \\
223\end{array}$ & $\begin{array}{r}6730 \\
306 \\
1683 \\
8719\end{array}$ & $\begin{array}{l}20 \\
21 \\
24 \\
65\end{array}$ & $\begin{array}{r}13 \cdot 3 \\
7 \cdot 0 \\
8 \cdot 4 \\
28 \cdot 6\end{array}$ & $\begin{array}{l}151 \\
302 \\
287 \\
227\end{array}$ & $\begin{array}{r}3226 \\
233 \\
1291 \\
4750\end{array}$ & $\begin{array}{r}59 \\
47 \\
46 \\
152\end{array}$ & $\begin{array}{l}30 \cdot 2 \\
16 \cdot 6 \\
20 \cdot 8 \\
67 \cdot 6\end{array}$ & $\begin{array}{l}195 \\
283 \\
221 \\
225\end{array}$ & $\begin{array}{r}9956 \\
539 \\
2974 \\
13469\end{array}$ \\
\hline
\end{tabular}

$\mathrm{O}=$ observed number of lung cancer deaths; $\mathrm{E}=$ expected number of lung cancer deaths.

who did not report a SIN to the chest clinics, 7941 (47\%) had submitted an income tax return in 1986 or 1987 and $4751(28 \%)$ had died leaving 4143 (25\%) unaccounted for. Altogether, 5934 of the 54208 miners (11\%) were neither known to be alive at the end of the study nor known to have died during the study period.

\section{EXCESS OF LUNG CANCER IN URANIUM MINERS}

The excess of lung cancer in the 7877 Ontario uranium miners who did not report SINs to the chest clinics was lower (observed $=139$, SMR $=$ 135) than in the 13469 Ontario uranium miners who did report their SINs to the chest clinics (observed $=152, \quad S M R=223$ ). The uranium miners who did not report SINs to the chest clinics worked in the uranium mines before 1965 and did not subsequently work as miners in Ontario. These results and the findings of the alive follow up study indicate that a large number of deaths in uranium miners who did not report SINs to the chest clinic were found in the Canadian Mortality database. It seems that the additional identifying information obtained from the SIN Registry permitted the identification of a much higher proportion of the deaths of Ontario miners. For these reasons, only the analysis of mortality from lung cancer in Ontario uranium miners whose SINs were recorded by the chest clinics is shown.

Many of the uranium miners also worked in gold mines and nickel and copper mines as well as in other types of mines in Ontario. Table 1 shows the number of uranium miners whose SIN was known, the number of these uranium miners who died from lung cancer, and the expected number of lung cancer deaths. These results are classified according to whether or not the miners mined nickel and copper and according to the year that the miner began gold mining for those uranium miners who also mined gold.

Overall, 152 lung cancer deaths were observed and 67.6 were expected giving a standardised mortality ratio (SMR) of 225 with a $95 \%$ confidence interval (95\% CI) of 191-264. The excess of lung cancer in uranium miners who also worked in nickel and copper mines (observed $=65, \mathrm{SMR}=$
227) did not seem to differ from the excess in uranium miners who did not work in nickel and copper mines (observed $=87$, SMR $=223$ ). There may however, be a larger excess of lung cancer in both the uranium miners who worked in gold mines before 1946 (observed $=47, \mathrm{SMR}=283$ ) and those who worked in gold mines after 1945 (observed $=46, S M R=221$ ) than in the uranium miners who did not mine gold (observed $=59$, SMR = 195).

Only two deaths from lung cancer occurred in uranium miners who began mining nickel and copper before 1935, the group of nickel and copper miners in whom an excess of lung cancer has been noted elsewhere. ${ }^{3}$ Twenty lung cancers were observed in the uranium miners who worked also in nickel and copper mines but did not mine gold, and 13.3 were expected (SMR $=151,95 \%$ CI 92-232). This excess is not greater than that found in uranium miners who mined neither gold nor nickel and copper $(S M R=230,95 \%$ CI 164-315).

LUNG CANCER MORTALITY FROM EXPOSURE TO SHORT LIVED RADON PROGENY AND ARSENIC

Table 2 shows the observed and expected numbers of deaths from lung cancer categorised according to attained age, the amounts of exposure to short lived radon progeny in each of two times since exposure windows, and the index of exposure to arsenic in gold mines lagged 20 years. The SMR for lung cancer in Ontario uranium miners increases with increasing age, with increasing exposure to short lived radon progeny in both time since exposure intervals, and with increase in the index of exposure to arsenic lagged 20 years.

The figure shows the SMRs for lung cancer in Ontario miners according to the intensity of exposure to arsenic lagged 20 years for uranium miners who accumulated less than and more than 40 WLM lagged 15 years. In uranium miners whose exposure to short lived radon progeny lagged 15 years was less than 40 WLM, the SMRs for lung cancer seem to increase linearly as the exposure to arsenic increases although a curvilinear function would also fit well with the SMRs. In uranium miners whose exposures to short lived radon 
Table 2 Lung cancer mortality and attained age, exposure to short lived radon decay progeny in two times since exposure windows, and the index of exposure to arsenic in gold mines.

\begin{tabular}{llll}
\hline & Observed & Expected & SMR \\
\hline Age group (y): & & & \\
$<55$ & 49 & $23 \cdot 4$ & 209 \\
$55-64$ & 65 & $29 \cdot 00$ & 225 \\
$65-74$ & 38 & $15 \cdot 2$ & 250
\end{tabular}

Exposure to radon decay progeny in the 5-14 year time window (WLM):

$\begin{array}{lrrr}0 & 54 & 29 \cdot 4 & 184 \\ >0-<20 & 57 & 24 \cdot 7 & 231 \\ 20-<40 & 13 & 5 \cdot 2 & 248 \\ 40-<70 & 15 & 3 \cdot 7 & 403 \\ 70-<140 & 5 & 2 \cdot 9 & 172 \\ \geqslant 140 & 8 & 1 \cdot 7 & 484\end{array}$

Exposure to short lived radon decay progeny lagged 15 years (WLM):

$\begin{array}{llrl}0 & & & \\ 0 & 21 & 11 \cdot 3 & 186 \\ >0-<20 & 43 & 25 \cdot 6 & 168 \\ 20-<40 & 22 & 9 \cdot 3 & 236 \\ 40-<70 & 23 & 8 \cdot 6 & 268 \\ 70-<140 & 29 & 7 \cdot 9 & 369 \\ \geqslant 140 & 14 & 5 \cdot 0 & 282\end{array}$

Index of exposure to arsenic lagged 20 years (\%As-y):

\begin{tabular}{lrrr}
0 & 71 & $35 \cdot 4$ & 200 \\
$>0-<0 \cdot 1$ & 15 & $7 \cdot 7$ & 196 \\
$0 \cdot 1-<0 \cdot 3$ & 12 & $7 \cdot 6$ & 158 \\
$0 \cdot 3-<1$ & 31 & $9 \cdot 6$ & 322 \\
$1-<3$ & 15 & $5 \cdot 2$ & 289 \\
$\geqslant 3$ & 8 & $2 \cdot 1$ & 383 \\
\hline
\end{tabular}

progeny lagged 15 years was greater than 40 WLM, the association between lung cancer SMRs and exposure to arsenic seems to be curvilinear. By contrast with the uranium miners with less than 40 WLM lagged 15 years, the SMRs for lung cancer in miners with more than 40 WLM lagged 15 years

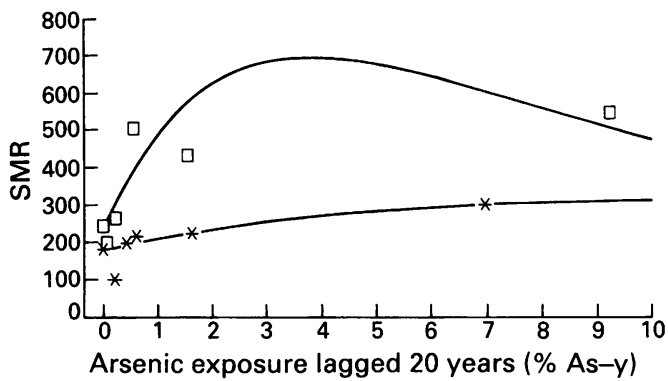

Figure Lung cancer mortality and exposure to arsenic and radon progeny. ${ }^{*}<40 \mathrm{WLM}_{15+} ; \square \geqslant 40 \mathrm{WLM}_{15+}$

seem to increase at a faster rate as exposure to arsenic increases but for high exposures to arsenic, reach a plateau and possibly decline.

A large number of different curvilinear functions could be used to describe the association between mortality from lung cancer and exposure to arsenic in these miners. A linear exponential is one such function. It has the form:

$$
\mathrm{O} / \mathrm{E}=\mathrm{i}+\mathrm{aAs} \mathrm{e}^{(-\mathrm{bAs})}
$$

where $O$ is the observed number and $E$ is the expected number of deaths from lung cancer, As is the index of exposure to arsenic lagged 20 years and $i, a$, and $b$ are calculated in the regression analysis. This function is linear when $b$ is set to zero and can have the general shape shown in the figure when $b$ is greater than zero. The figure shows the equation fitted to the excess of lung cancer for both groups of uranium miners.

Table 3 shows the results of a Poisson regression

Table 3 Lung cancer mortality in all Ontario uranium miners: combined effects of exposure to short lived radon progeny and arsenic

\begin{tabular}{|c|c|c|c|c|c|c|}
\hline \multirow[b]{2}{*}{ Model for $O / E$} & \multirow[b]{2}{*}{ Deviance } & \multirow[b]{2}{*}{$\begin{array}{l}\text { Degrees } \\
\text { of } \\
\text { freedom }\end{array}$} & \multicolumn{3}{|c|}{ Freeman-Tukey Residuals } & \multirow[b]{2}{*}{ Model } \\
\hline & & & $G^{2}$ & $\begin{array}{l}\text { Degrees } \\
\text { of } \\
\text { freedom }\end{array}$ & $\begin{array}{l}\text { Number } \\
\text { of } \\
\left|g_{i}\right|>2\end{array}$ & \\
\hline $2 \cdot 25$ & $335 \cdot 67$ & 513 & $195 \cdot 87$ & 155 & 4 & 1 \\
\hline $1.61+0.012 \mathrm{WLM}_{5}$ & $323 \cdot 11$ & 512 & $188 \cdot 23$ & 171 & 3 & 2 \\
\hline $1.50+0.011 \mathrm{WLM}_{5}+0.31 \mathrm{As}$ & $318 \cdot 22$ & 511 & $186 \cdot 42$ & 176 & 3 & 3 \\
\hline $\begin{array}{l}1.62+0.0097\left(\mathrm{WLM}_{5-14}+0.85 \mathrm{WLM}_{15+}\right) \\
\left(1.8 \mathrm{~A}_{1}+\mathrm{A}_{2}+1.3 \mathrm{~A}_{3}\right)\end{array}$ & $321 \cdot 79$ & 509 & $186 \cdot 98$ & 168 & 3 & 4 \\
\hline $\begin{array}{l}1.61+0.0089\left(\mathrm{WLM}_{5-14}+0.87 \mathrm{WLM}_{15+}\right) \\
\left(2.0 \mathrm{~A}_{1}+\mathrm{A}_{2}+1.2 \mathrm{~A}_{3}\right)+0.0145 \mathrm{As} \mathrm{e}^{(0.19 \mathrm{As})}\end{array}$ & $315 \cdot 37$ & 507 & $184 \cdot 31$ & 167 & 3 & 5 \\
\hline $\begin{array}{l}1.40+0.0096\left(\mathrm{WLM}_{5-14}+0.49 \mathrm{WLM}_{15}+\right) \\
\left(2.3 \mathrm{~A}_{1}+\mathrm{A}_{2}+0.6 \mathrm{~A}_{3}\right)+0.077 \mathrm{As} \mathrm{WLM}_{15+} \mathrm{e}^{\left(-0.011 \mathrm{AswLM}_{15+}\right)}\end{array}$ & $310 \cdot 49$ & 507 & $181 \cdot 97$ & 172 & 2 & 6 \\
\hline $\begin{array}{l}1.63+0.0073\left(W_{L} M_{5-14}+1.01 W_{L} M_{15+}\right) \\
\left(2.1 A_{1}+A_{2}+1.4 A_{3}\right)+0.0060 \text { As WLM } \\
\left.5-14 e^{\left(-0.00011 A_{s} W_{L-14}\right.}\right)\end{array}$ & $319 \cdot 38$ & 507 & $186 \cdot 91$ & 168 & 3 & 7 \\
\hline $\begin{array}{l}1.62\left(1+0.0058\left(\mathrm{WLM}_{5-14}+0.85 \mathrm{WLM}_{15+}\right)\right. \\
\left(1.9 \mathrm{~A}_{1}+\mathrm{A}_{2}+1.0 \mathrm{~A}_{3}\right) \times\left(1+0.0048 \mathrm{As} \mathrm{e}^{(0.20 \mathrm{As})}\right)\end{array}$ & 315.51 & 507 & $184 \cdot 41$ & 167 & 3 & 8 \\
\hline
\end{tabular}


Table 4 Ever regular cigarette smokers in Ontario uranium miners and year of birth cohorts, and exposure to arsenic and short lived radon progeny

\begin{tabular}{|c|c|c|c|c|c|c|c|c|c|c|}
\hline \multirow[b]{2}{*}{$\begin{array}{l}\text { Year of } \\
\text { birth }\end{array}$} & \multirow{2}{*}{$\begin{array}{l}\text { No } \\
\text { in } \\
\text { sample }\end{array}$} & \multirow[b]{2}{*}{$\begin{array}{l}\% \text { Ever } \\
\text { smoker }\end{array}$} & \multicolumn{2}{|c|}{$<40 W L M$} & \multicolumn{2}{|c|}{$\geqslant 40 W L M$} & \multicolumn{2}{|c|}{$<1 \% A s-y$} & \multicolumn{2}{|c|}{$\geqslant 1 \% A s-y$} \\
\hline & & & No & $\begin{array}{l}\% \text { Ever } \\
\text { smoker }\end{array}$ & No & $\begin{array}{l}\% \text { Ever } \\
\text { smoker }\end{array}$ & No & $\begin{array}{l}\% \text { Ever } \\
\text { smoker }\end{array}$ & No & $\begin{array}{l}\% \text { Ever } \\
\text { smoker }\end{array}$ \\
\hline $\begin{array}{l}1898-1910 \\
1910-19 \\
1920-29 \\
1930-39 \\
1940-49 \\
1950-63 \\
\text { Total }\end{array}$ & $\begin{array}{r}17 \\
165 \\
615 \\
1234 \\
1042 \\
1718 \\
4791\end{array}$ & $\begin{array}{l}65 \\
84 \\
85 \\
81 \\
83 \\
77 \\
80\end{array}$ & $\begin{array}{r}3 \\
46 \\
254 \\
681 \\
862 \\
1583 \\
3429\end{array}$ & $\begin{array}{l}67 \\
80 \\
87 \\
80 \\
84 \\
77 \\
80\end{array}$ & $\begin{array}{r}14 \\
115 \\
351 \\
528 \\
135 \\
7 \\
1150\end{array}$ & $\begin{array}{l}64 \\
85 \\
84 \\
81 \\
79 \\
86 \\
82\end{array}$ & $\begin{array}{r}6 \\
66 \\
169 \\
243 \\
133 \\
24 \\
641\end{array}$ & $\begin{array}{l}67 \\
83 \\
86 \\
81 \\
87 \\
83 \\
84\end{array}$ & $\begin{array}{r}5 \\
25 \\
55 \\
50 \\
18 \\
0 \\
153\end{array}$ & $\begin{array}{l}80 \\
88 \\
82 \\
80 \\
89 \\
\\
\end{array}$ \\
\hline
\end{tabular}

analysis of the relation between the excess relative risk of mortality from lung cancer in uranium miners and exposures to arsenic and short lived radon progeny. The Freeman-Tukey residuals are used to determine how well the model fits the data ${ }^{4}$ and the deviances are used to rank the goodness of fit of each of the models.

The analysis shows that exposure to short lived radon progeny either adjusted for attained age and time since exposure $\left(\chi^{2}{ }_{4} 13.88, p=0.008\right)$ or lagged five years $\left(\chi^{2}, 12 \cdot 58, p=0.0004\right)$ is related to the excess relative risk of mortality from lung cancer. Comparing the deviances of models 2 and 3 shows that the excess relative risk of mortality from lung cancer in uranium miners is also associated with exposure to arsenic $\left(\chi^{2}{ }_{1} 4 \cdot 89, \mathrm{p}=0.03\right)$.

Models 5 to 8 were used to determine how exposure to arsenic affects mortality from lung cancer. Particular attention was given to whether exposure to short lived radon progeny affects the risk of lung cancer from exposure to arsenic. Although the Freeman-Tukey residuals show that models 5 to 8 each fit well to the data, the deviances indicate that model 6 fits best.

The regression analysis indicates that in uranium miners, exposure to arsenic seems to be associated with lung cancer mortality $\left(\chi^{2}{ }_{2}=6.42, p=0.04\right)$ independently of the amount of exposure to short lived radon progeny. Further analysis indicates however, that the relative excess of lung cancer mortality from the same degree of exposure to arsenic depends on the amount of exposure to short lived radon progeny lagged 15 years $\left(\chi_{2}^{2}=11 \cdot 30\right.$, $P=0.004$ ) but not on exposure to short lived radon progeny in the five to 14 year time window $\left(\chi_{2}^{2}=2 \cdot 41, \mathrm{p}=0.3\right)$.

A multiplicative model for the combined effect of these two exposures, model 8, shows that exposure to arsenic lagged 20 years is associated with lung cancer mortality in Ontario uranium miners $\left(\chi_{2}^{2}=6 \cdot 28, p=0.04\right)$.

\section{SMOKING HABITS OF URANIUM MINERS}

The smoking histories of 4791 uranium miners were obtained. There were 2961 individual smoking histories obtained from the chest clinics, 1307 from the 1990-91 postal questionnaire, 764 from the 1974 survey of active uranium miners, and 207 from the sample of uranium miners born before 1938. The smoking histories for some uranium miners were obtained from more than one source. The reply to the question asking if the miner had ever smoked cigarettes was the same in $252(93 \%)$ of the 270 men from whom the history was taken both by a chest clinic and another of the surveys.

The results of these surveys were combined and table 4 shows the results. About $20 \%$ of the uranium miners in these surveys reported that they had never smoked cigarettes regularly.

A logistic regression analysis of the smoking histories showed that an association between the proportion of uranium miners who never regularly smoked cigarettes and the miner's year of birth could be detected $\left(\chi^{2}{ }_{1} 24 \cdot 2, p=9 \times 10^{-7}\right)$. The results of the logistic regression analysis also indicate that the proportion of uranium miners who never regularly smoked cigarettes increases $2 \%$ for each 10 year increment in the year of birth.

There may also be proportionately fewer smokers among men heavily exposed to arsenic $\left(\chi_{1}^{2} 2 \cdot 6\right.$, $\mathrm{p}=0 \cdot 1)$ and a greater number of smokers among uranium miners who also mined gold $\left(\chi^{2}{ }_{1} 2 \cdot 1\right.$, $p=0 \cdot 1)$. No association between the proportion of smokers and cumulative exposure to short lived radon progeny could be detected.

\section{HISTOLOGY}

Table 5 shows the distribution of the major types of carcinoma of the lung in the uranium miners as determined by review of the histological material. For comparison, the table shows the distribution of the different types of carcinoma in 3514 cases in four series of patients reported previously. ${ }^{8-11}$ In uranium miners the proportion of small cell carcinomas, $44 \%$ (95\% CI $36-53 \%)$ is larger than in the control series $(15-23 \%)$. The findings also suggest that in the miners, small cell carcinomas may cause death at an earlier age than do other types of carcinoma of the lung. 
Table 5 Lung cancer in uranium miners, in a control series; and after exposure to short lived radon progeny: histological types

\begin{tabular}{|c|c|c|c|c|c|c|}
\hline \multirow[b]{2}{*}{ Cell type } & \multirow[b]{2}{*}{$\begin{array}{l}\text { No } \\
(\%)\end{array}$} & \multirow[b]{2}{*}{$\begin{array}{l}\text { Mean } \\
\text { age } \\
(y)\end{array}$} & \multirow{2}{*}{$\begin{array}{l}\text { Range of } \\
\text { results } \\
\text { in } \\
\text { control } \\
\text { series } \\
(\%)\end{array}$} & \multicolumn{3}{|c|}{$\begin{array}{l}\text { Average exposure to short lived radon } \\
\text { progeny (WLM) }\end{array}$} \\
\hline & & & & $\begin{array}{l}\text { Up to five } \\
\text { years before } \\
\text { death }\end{array}$ & $\begin{array}{l}\text { Up to } 15 \\
\text { years } \\
\text { before } \\
\text { death }\end{array}$ & $\begin{array}{l}\text { Five to } 14 \\
\text { years } \\
\text { before } \\
\text { death }\end{array}$ \\
\hline $\begin{array}{l}\text { Squamous } \\
\text { Adenocarcinoma } \\
\text { Large cell } \\
\text { Small cell } \\
\text { Other }\end{array}$ & $\begin{array}{r}29(20 \cdot 4) \\
20(14 \cdot 1) \\
24(16 \cdot 9) \\
63(44 \cdot 4) \\
6(4 \cdot 2)\end{array}$ & $\begin{array}{l}61 \\
62 \\
59 \\
57 \\
58\end{array}$ & $\begin{array}{r}25-41 \\
17-44 \\
7-17 \\
15-23 \\
-\end{array}$ & $\begin{array}{l}64 \cdot 5 \\
63 \cdot 5 \\
66 \cdot 5 \\
77 \cdot 4 \\
67 \cdot 0\end{array}$ & $\begin{array}{l}48 \cdot 7 \\
46 \cdot 2 \\
58 \cdot 4 \\
44 \cdot 9 \\
55 \cdot 3\end{array}$ & $\begin{array}{r}15 \cdot 8 \\
14 \cdot 0 \\
8 \cdot 2 \\
32 \cdot 6 \\
11 \cdot 7\end{array}$ \\
\hline
\end{tabular}

A logistic regression analysis of the relation between the proportion of small cell lung tumours in this sample and age at death, exposure to short lived radon progeny accumulated up to five years before death, up to 15 years before death, and in the time interval five to 14 years before death was done. The analysis shows that the proportion of small cell tumours in the sample increased with both younger age at death $\left(\chi^{2}{ }_{1} 4 \cdot 7, p=0.03\right)$ and increasing exposure to short lived radon progeny five to 14 years before death $\left(\chi^{2}{ }_{1} 6 \cdot 1, p=0 \cdot 01\right)$. After adjustment for age at death, an association between exposure to short lived radon progeny in the time interval five to 14 years before death and the proportion of small cell lung tumours is still found $\left(\chi^{2}{ }_{1} 3.9, p=0.05\right)$.

\section{Discussion}

COMPLETENESS OF ASCERTAINMENT OF MORTALITY The results of the alive follow up and the mortality search show that $25 \%$ of the miners who did not report their SINs to the chest clinics could not be located at the end of the study period. This may indicate that some deaths in the study groups have not been found, probably because the information about name, sex, date, and place of birth alone are not sufficient to find all deaths in the Canadian Mortality Database.

The fact that mortality from lung cancer in Ontario uranium miners who did not report SINs to the chest clinic was lower than that of other Ontario uranium miners supports the hypothesis that not all of the deaths in Ontario uranium miners were found in the Canadian Mortality Database. The association between the relative excess of lung cancer mortality and exposure to short lived radon progeny and arsenic was examined in uranium miners who did not report SINs to the chest clinics. The numerical results are not shown here, but they indicate that the associations between mortality from lung cancer and exposure to arsenic and short lived radon decay products were the same as those in uranium miners who did report their SINs to the chest clinics. The calculated constant term in the regression equation however, was found to be much lower in uranium miners who did not report SINs to the chest clinics than in the other uranium miners. This adds support to the hypothesis that SINs make an important contribution to finding deaths in the Canadian Mortality Database.

\section{SMOKING}

A survey of the smoking habits of Canadian males ${ }^{12}$ shows that in 1966 about $71 \%$ of men born between 1911 and 1935 were or had been regular cigarette smokers. The survey also showed that smoking habits of males in Ontario and Canadian males are similar. About $80 \%$ of the uranium miners are or were regular cigarette smokers. Comparison of the number of smokers in uranium miners and male Canadians born at the same time suggests that the larger proportion of smokers among uranium miners would probably increase their mortality from lung cancer by between $10 \%$ and $20 \%$ compared with males in Ontario. ${ }^{13}$

No correlation between smoking and exposure to either arsenic or short lived radon progeny was found, making it improbable that smoking contributed to the increased incidence of lung cancer associated with exposure to these agents.

\section{LUNG CANCER MORTALITY AND EXPOSURE TO SHORT LIVED RADON PROGENY}

This and our earlier reports ${ }^{12}$ show that exposure to short lived radon progeny in the uranium mines contributes to the increased mortality from lung cancer in Ontario uranium miners. The association between the excess of lung cancer mortality and exposure to short lived radon progeny shown in this report is similar to that reported when the period of observation for mortality was shorter. ${ }^{2}$

A study of mortality from lung cancer in several populations of uranium miners including this group shows that both attained age and time since exposure affect the relation between the excess of lung cancer mortality and exposure to short lived radon progeny. ${ }^{4}$ It found that the excess relative risk of lung cancer resulting from the same exposure to 
short lived radon progeny was greatest in miners under the age of 55 and least in miners over the age of 65 . It was greater five to 14 years after exposure to short lived radon progeny than in subsequent years. Our present study supports these conclusions.

\section{EXPOSURE TO SHORT LIVED RADON PROGENY AND ARSENIC}

The mortality from lung cancer in Ontario uranium miners who also mined gold is related both to exposure to short lived radon progeny and to exposure to arsenic. In Ontario gold miners who did not mine uranium, mortality from lung cancer is associated with exposure to short lived radon progeny in the gold mines and to exposure to arsenic before 1946, but not with exposure to arsenic subsequently. ${ }^{3}$ In the uranium miners who also mined gold, it is associated with exposure to arsenic both before and after 1946.

In gold miners who never mined uranium or who were exposed in the uranium mines to less than 40 WLM lagged 15 years, the relation between the relative excess of lung cancer mortality and exposure to arsenic seems to be linear. In uranium miners who mined gold and were exposed to at least 40 WLM lagged 15 years, a curvilinear association between the excess of lung cancer mortality and exposure to arsenic was evident.

The regression analysis showed that in uranium miners, the mortality from lung cancer associated with exposure to arsenic increased as the amount of exposure to short lived radon progeny increased. In gold miners who did not mine uranium, the two exposures seemed to act independently on lung cancer mortality. Only 17 of the 307 gold miners who did not mine uranium and who died from lung cancer were exposed to more than 40 WLM and most of the gold miners who did not mine uranium and died from lung cancer were exposed to less than 15 WLM. The higher exposure to short lived radon progeny in the uranium mines seems to have increased lung cancer mortality associated with exposure to arsenic. This finding is consistent with the report that exposure to arsenic increases lung cancer mortality from other carcinogenic agents. ${ }^{14}$

The regression analysis indicates also that in Ontario uranium miners the risk from exposure to arsenic begins 20 years after the exposure to arsenic and that the risk from exposure to short lived radon progeny begins five years after exposure. The effect of exposure to arsenic depends upon the amount of exposure to short lived radon progeny lagged 15 years but not on that in the five to 14 year time window.

The dose from short lived radon progeny is delivered to lung tissue within hours of inhalation but inhaled arsenic may be retained in the lung for several years, depending on its chemical and physical characteristics. Hence it is difficult to measure the timing of the doses to lung tissue for these exposures solely on the basis of the time of exposure in the mines. Despite these difficulties, it seems that the timing of the exposures to arsenic and short lived radon progeny is important in lung cancer mortality.

The greater proportion of current and former smokers in uranium miners than in Ontario men is compatible with a 10 to $20 \%$ increase in the lung cancer mortality of Ontario uranium miners but cannot explain the whole excess of lung cancer in the uranium miners.

A case control study of tin miners in China considered the incidence of lung cancer in miners and smelter workers who accumulated up to 1762 WLM of exposure to short lived radon progeny, some of whom were exposed to between 0.01 and $0.42 \mathrm{mg}$ of airborne arsenic per $\mathrm{m}^{3} .15$ The association between the incidence of lung cancer and exposure to arsenic seems to be linear when exposure to short lived radon progeny is less than 89 WLM and it seems to be curvilinear when exposure to short lived radon progeny is greater than 89 WLM. The curvilinear association between lung cancer mortality and the higher exposure to short lived radon progeny in the tin miners in China may be similar to that seen in Ontario uranium miners.

\section{HISTOLOGY}

The incidence of small cell carcinomas in Ontario uranium miners is greater than in a control series. Other studies of carcinoma of the lung in miners exposed to short lived radon progeny have shown a similar excess of small cell carcinomas. ${ }^{4}$

The increase in the proportion of small cell carcinomas in Ontario uranium miners is particularly pronounced when exposure to short lived radon progeny occurs five to 14 years before death. This may explain why mortality from lung cancer in uranium miners is greatest when the exposure to radon decay products occurs during this time.

\section{Conclusions}

Mortality from lung cancer is greater among Ontario uranium miners than in the general male population of Ontario. Part of the increase is clearly related to exposure to short lived radon progeny.

Mortality from lung cancer in the men who worked in both the gold mines and the uranium mines is due both to exposure to arsenic and to short lived radon progeny. The amount of exposure to short lived radon progeny seems to determine the size of the increase in mortality from lung cancer caused by exposure to arsenic.

Part of the excess of lung cancer may be because 
the proportion of men who are smokers or have smoked is greater in uranium miners than in Ontario males. Because there is no association between smoking and the amount of exposure to radon and arsenic, however, smoking is not likely to be responsible for all of the increase in mortality from lung cancer.

The preferred equation that describes mortality from lung cancer in Ontario uranium miners is: $\mathrm{O} / \mathrm{E}=1.40+0.0096\left(\mathrm{WLM}_{5-14}+0.49 \mathrm{WLM}_{15+}\right)$ $\left(2.3 \mathrm{~A}_{1}+\mathrm{A}_{2}+0.6 \mathrm{~A}_{3}\right)+0.077$ As $\mathrm{WLM}_{15+}$ $\mathrm{e}^{\left(-0.011 \text { As } \text { WLM M }_{15+}\right)}$

Where $O$ is the observed number of lung cancer deaths, $\mathrm{E}$ is the expected number of lung cancer deaths, $\mathrm{WLM}_{5}$ is cumulative exposure to short lived radon progeny lagged five years, $\mathrm{WLM}_{15+}$ is cumulative exposure to short lived radon progeny lagged 15 years, $\mathrm{WLM}_{5-14}=\mathrm{WLM}_{5+}-\mathrm{WLM}_{15+}$, As is the index of exposure to arsenic lagged 20 years (\% arsenic in rock $\times$ years of employment underground), $A_{1}=1$ when age is less than 55 years and 0 otherwise, $A_{2}=1$ when age is between 55 and 64 and 0 otherwise, $A_{3}=1$ when age is between 65 and 74 and 0 otherwise

In Ontario uranium miners, the proportion of lung cancers that are small cell carcinomas is increased and is associated most with the amount of exposure to short lived radon progeny that occurs five to 14 years before death. In Ontario uranium miners, the proportion of the tumours that are small cell carcinomas decreases as age increases.

The Ontario Ministry of Labour, the Workers' Compensation Board of Ontario, and the Atomic Energy Control Board provided the funds for this study.

Ms Irene Rule was indispensable in keeping track of the data and Ms Rose Pagliaro assisted in data entry. John Vergunst collected the data about the levels of short lived radon progeny in gold mines in Ontario. Dr Jaan Roos provided smoking histories from the chest clinics' database. Mr Colin Benjamin and Ms Elizabeth Grosselfeuger coordinated the review of the tissue samples. Pierre Lalonde of the Occupational and Environmental Health Research Section at Statistics Canada did the alive follow up of Ontario miners. Geoff Howe provided useful comments about an earlier version of this report.

Access to the death records at the National
Centre for Health Information at Statistics Canada was granted by the Registrar-General of each Province and Territory in Canada. Cooperation in locating hospital records was provided by the Ontario Cancer Treatment and Research Foundation, the British Columbia Cancer Control Agency, Alberta Cancer Agency, the Saskatchewan Cancer Foundation, Manitoba Cancer Treatment and Research Foundation, Ministère de la Santé et des Services Sociaux du Québec, New Brunswick Tumour Registry, and the Cancer Treatment and Research Foundation of Nova Scotia.

1 Muller J, Wheeler WC, Gentleman JF, Suranyi G, Kusiak RA. Study of Mortality of Ontario miners 1955-1977 part 1. Toronto: Ontario Ministry of Labour, Ontario Workers' Compensation Board, Atomic Energy Control Board of Canada 1983.

2 Muller J, Kusiak R, Ritchie AC. Factors modifying lung cancer risk in Ontario uranium miners 1955-1981. Toronto: Ontario Ministry of Labour, Workers' Compensation Board of Ontario, Atomic Energy Control Board of Canada. July 1989.

3 Kusiak RA, Springer J, Ritchie AC, Muller J. Lung cancer mortality in Ontario gold miners: possible aetiological factors. Br $\mathcal{F}$ Ind Med 1991;48:808-17.

4 Committee on the biological effects of ionizing radiation (BEIR IV). Health risks of radon and other alpha emitters. Washington, DC: National Academy Press, 1988.

5 Hawley J. The chemical characteristics of mineral tailings in the Province of Ontario. Toronto: Ontario Ministry of Environment, 1980.

6 World Health Organisation. International classification of diseases, Vol 1 (second edition). Geneva: WHO, 1981.

7 Ontario Ministry of Health. Survey of certain conditions of the respiratory organs among persons employed underground and in surface crushers and mills of two operating uranium mines at Elliot Lake, Ontario. Toronto: Ontario Ministry of Health, 28 April 1975

8 Beard CM, Jedd MB, Woolner LB, Richardson RL Bergstrahl EJ, Melton LJ, III. Fifty-year trend in incidence rates of bronchogenic carcinoma by cell types in Olmstead County, Minnesota. $\mathcal{F}$ Natl Cancer Inst 1988;80:1404-7.

9 Cox JD, Yesner Ra. Adenocarcinoma of the lung. Am Rev Respir Dis 1979;120:1025-9.

10 Valaitis J, Warren S, Gamble D. Increasing incidence of adenocarcinoma of the lung. Cancer 1981;47:1042-6.

11 Vincent RG, Pickren JW, Lane WW, Bross I, Takita H, Houten $\mathrm{L}$, et al. The changing histopathology of lung cancer. Cancer 1977;39:1647-55.

12 Wheatley G. Smoking habits of Canadians 1965 to 1979. Ottawa: Health and Welfare Canada, December 1980. (Tech rept. series No 9.)

13 Axelson $O$. Aspects of confounding in occupational health epidemiology. Scand f Work Environ Health 1978;4:98-102.

14 Magos L. Epidemiological and experimental aspects of metal carcinogenesis: physicochemical properties, kinetics and the active species. Environ Health Perspect 1991;95:157-89.

15 Taylor PR, Qiao Y-L, Schatzkin A, Yao S-X, Lubin J, Mao B-L, et al. Relation of arsenic exposure to lung cancer among tin miners in Yunnan Province, China. $\mathrm{Br} \mathcal{F}$ Ind Med 1989;46:881-6.

Accepted 14 December 1992 